\title{
Geometry Morphometry and Health Status of Hawksbill Turtle (Eretmochelys imbricata Linnaeus, 1766) in Maratua Island, East Kalimantan-Indonesia
}

\section{Firly Fathiya Maulida1, Susilo Hadi', Muhammad Ali Imron², and Thomas Reischig ${ }^{3}$}

${ }^{1}$ Faculty of Biology, Universitas Gadjah Mada, Jalan Teknika Selatan, Sekip Utara, Yogyakarta 55281 , Indonesia

${ }^{2}$ Wildlife Ecology and Management, Faculty of Forestry Universitas Gadjah Mada, Jalan Agro no 1 Bulaksumur, Yogyakarta 55281 Indonesia

${ }_{3}^{3}$ Turtle Foundation Deutschland, Reinhäuser Landstr. 41 D-37083 Göttingen, Germany

\section{Abstract}

Research on hawksbill turtles in the Maratua Island is still very few. Meanwhile, population of hawksbills was believed to decline due to human exploitation. The aim of this research was to study the morphology of hawksbill through geometric morphometric approach and health status which includes the existence of epibionts, mechanical damages and Body Condition Index. The survey was conducted from 5 to 18 September 2014. The method used was the hand-catching by snorkeling and

Corresponding Author: Firly Fathiya Maulida firlyfathiya.m@gmail.com

Received: 11 February 2017

Accepted: 08 March 2017

Published: 26 March 2017

Publishing services provided by Knowledge $\mathrm{B}$

(c) Firly Fathiya Maulida et al. This article is distributed under the terms of the

Creative Commons Attribution

License, which permits

unrestricted use and

redistribution provided that

the original author and source are credited.

Selection and Peer-review under the responsibility of the ICBS Conference Committee.

G OPEN ACCESS diving for catching turtles, morphometric measurements and documentation of the turtle body parts using the camera. Morphological aspects were analyzed with linear regression and geometry approach with Microsoft Excel and ImageJ software. Health status was analyzed with observation of epibionts and mechanical damages through photos and calculation of Body Condition Index. There were 11 turtles that have been caught. The results indicated the growth of straight carapace length notch to tip affect the growth of the other body parts of hawksbill turtle and based approach to geometry, shape growth of hawksbill turtles that are found in Maratua not changed but only have added size. Based on the health status through observation epibionts, mechanical damages and analysis of Body Condition Index, hawksbill in Maratua still relatively healthy compared with studies elsewhere.

Keywords: Eretmochelys imbricato (Linnaeus, 1766); geometry; Maratua; morphometry.

\section{Introduction}

East Kalimantan is one of four bio-breeding grounds and distribution regional of sea turtles [1]. Maratua Island is the distribution regional of Hawksbill turtle [Eretmochelys imbricata (Linnaeus, 1766)] in Derawan Islands, East Borneo. Hawksbill turtles are often found while nesting and seen on foraging areas in there, but the number of hawksbills 
is yet to be ascertained [2]. Research on hawksbill turtles in the Maratua Island is still very rarely done, whereas until now the existence of hawksbill turtles in the place believed to be declining due to human activities. Hawksbill turtle needs to be preserved because it has an important role in the life cycle of the sea by maintaining the stability of the sponge population because the main food of hawksbill turtle is a sponge [3].

In addition to studying the variations in the shape of the body, research on morphometry also important to learn about the causation [4]. The study of causation is likely to explain the relationship between human activities with the morphology of turtles on a particular area. One example (species) in the case of overfishing. Overfishing will cause the body size variations of the fish population left in the wild and the food chain became unbalanced. The case is likely to be used as an example for research on the relationship of the turtles population body size in a particular area related to hunting activities [5].

As the animal that migrate in great distance, turtle will experience a lot of stress and environmental changes that can affect it health. During the migration, turtles will undergo physiological stress such as changes in temperature, currents, light, salinity and can also interact with other biota that acts as epibiont such as barnacles. Epibionts is an organism that attaches to the body of other organisms and can be used as one of indicator of the turtle health [6].

\section{Materials and Methods}

\subsection{Study area}

The survey was conducted on September 5th, 2014 to September 18th, 2014. All turtles were captured on the reef edge of Bakungan Kecil $\left(2^{\circ} 12^{\prime} \mathrm{N}, 118^{\circ} 35^{\prime} \mathrm{E}\right.$ ) (Nunukan Resort Island); Teluk Bayur-Gusung Tengah $\left(2^{\circ} 16^{\prime} \mathrm{N}, 118^{\circ} 37^{\prime} \mathrm{E}\right)$, Lumantang Besar $\left(2^{\circ} 11^{\prime} \mathrm{N}, 118^{\circ} 35^{\prime} \mathrm{E}\right)$, Payung-payung ( $\left.2^{\circ} 08^{\prime} \mathrm{N}, 118^{\circ} 32^{\prime} \mathrm{E}\right)$ (Maratua Island); Manimpa $\left(2^{\circ} 08^{\prime} \mathrm{N}, 118^{\circ} 31^{\prime} \mathrm{E}\right)$, Lokan Balelo $\left(2^{\circ} 09^{\prime} \mathrm{N}, 118^{\circ} 31^{\prime} \mathrm{E}\right)$, Tong Dangkaan $\left(2^{\circ} 09^{\prime} \mathrm{N}, 118^{\circ} 32^{\prime} \mathrm{E}\right)$ (Kakaban Island).

\subsection{Data collection}

Hawksbill turtles on this study were captured by hand-catching method (snorkling) at day and by hand-catching method (scuba diving) at night with help from local peoples. The "Rodeo Method" has been tried also at the first survey, but we judged this method as generally unsuitable for this location and ineffective. All captured turtles were photographed and measured for straight carapace length notch to notch (SCLnn), straight carapace length notch to tip (SCLnt), straight carapace width (SCW), curved 


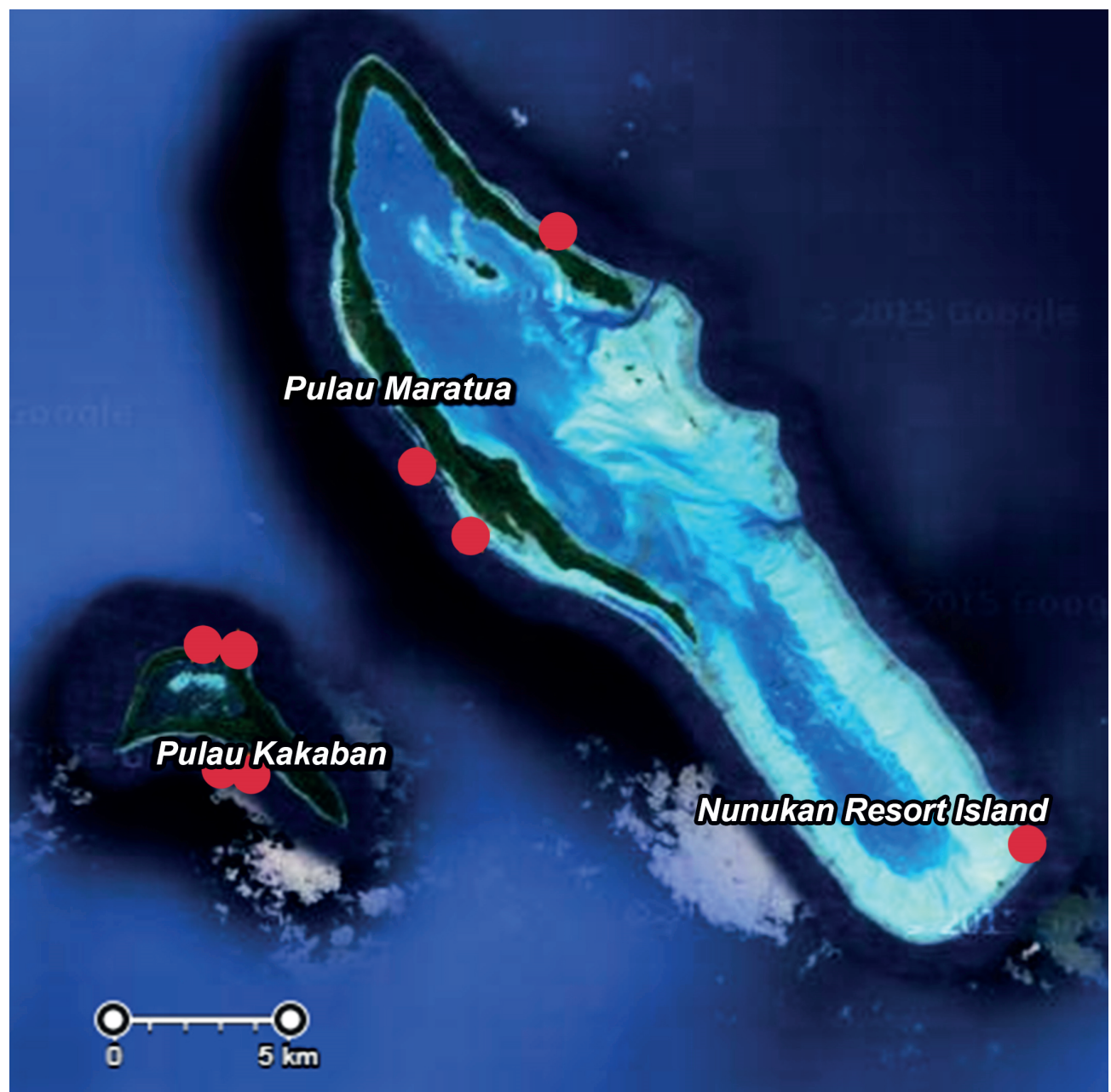

Figure 1: Map of Maratua Island with turtles capturing sites (red dots).

carapace length notch to notch (CCLnn), curved carapace length notch to tip (CCLnt), curved carapace width (CCW), straight midline plastron length (SMPL), head length, head width and tail length. All turtles were checked for diseases, parasites and external injuries.

\subsection{Data analysis}

The geometry aspect studied by turtles carapace shape and size comparison based on landmarks from every carapace, then associated with the growth form. Landmarks of the carapace created from a photo of each turtles with software Imagej which generated data in the form of XY coordinates. Coordinates that have been generated are presented in graphical form through the software Microsoft Excel. Based on data from morphometric measurements were taken, linear regression analysis is used to study the relationship between variations in the structure of the body and detect changes in body shape due to the increased size of the turtle [7]. Analysis was conducted on 


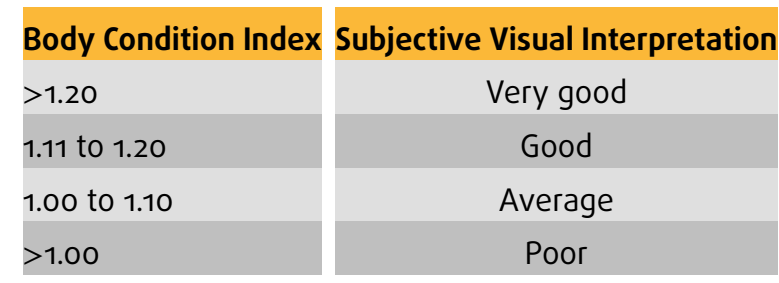

TABLE 1: Interpretation of Body Condition Index [8].

the relationship between SCLnt to body mass, SCLnt to carapace surface area, SCLnt to SCW and SCLnt to head width. Data analysis was performed with the help of the software Microsoft Excel.

Health status learned through direct observation and observartion of photos. Observations were made on the existence of epibionts barnacles and algae on each body parts. Body Condition Index calculated by the ratio of the weight and length of the straight carapace based Fulton's formula:

$$
\text { Body Condition Index }=\frac{\text { mass }}{\mathrm{SCL}^{3}} \times 10^{4}
$$

\section{Result and Discussion}

Obtained 11 hawksbill turtles were captured in this study. The whole turtles having variations in size from small to medium, although the number of turtles being measured is very limited, the data which generated can indicate a relationship between the units of measurement that can be seen in Figure 2.

Turtles are found in this study had a length of the straight carapace notch to tip measured $43.09 \mathrm{~cm} \pm 6.11 \mathrm{~cm}$ (mean $\pm \mathrm{SD}$ ). In the study of morphometry hawksbill previously by Blumenthal et al. [9] in the foraging ground in the Western Caribbean had carapace length measured $33.7 \mathrm{~cm} \pm 8.6 \mathrm{~cm}(n=125)$ in the area of Little Cayman and had measured at $31.4 \mathrm{~cm} \pm 7.4 \mathrm{~cm}(n=93)$ in the area of Grand Cayman. Then earlier research by van Dam and Diez [7] in the Caribbean, found 53 hatchling hawksbill turtles with carapace length measured $4.00 \mathrm{~cm} \pm 0.02 \mathrm{~cm}$ and hawksbill juveniles to adults with a range of a length of the SCLnt from $20.0 \mathrm{~cm}$ to $91.8 \mathrm{~cm}$. Based on comparisons with that previous studies, hawksbill in Maratua were captured in this study range from juvenile to semi-adult age.

Figure 2 shows that the SCLnt in a linear effect on the carapace surface area with $\mathrm{R}^{2}$ $=0.9425$, indicating a strong correlation (94.25\%) between SCLnt with a carapace surface area. Such is the case of that comparison, the comparison between other unit measurements had linearly correlation with each value $\mathrm{R}^{2}=0.9593$ (correlation $=95.93 \%$ ) in SCLnt vs. SCW, $\mathrm{R}^{2}=0.9851$ (correlation $=98.51 \%$ ) in SCLnt vs. body 


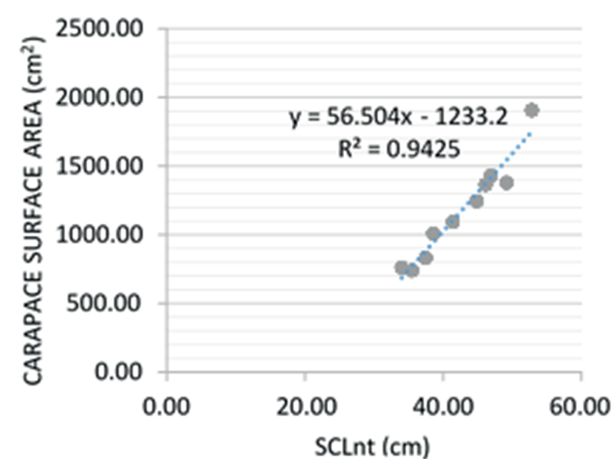

(a)

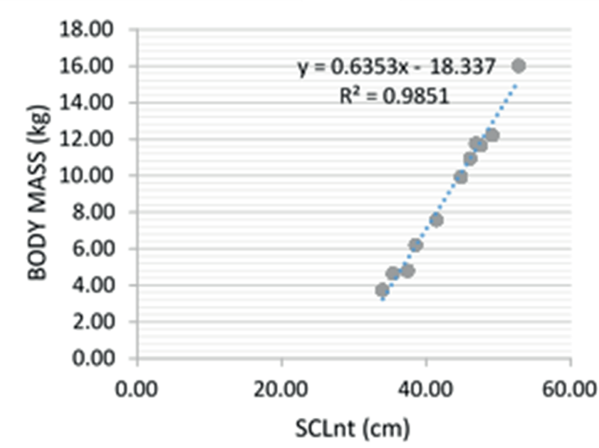

(c)

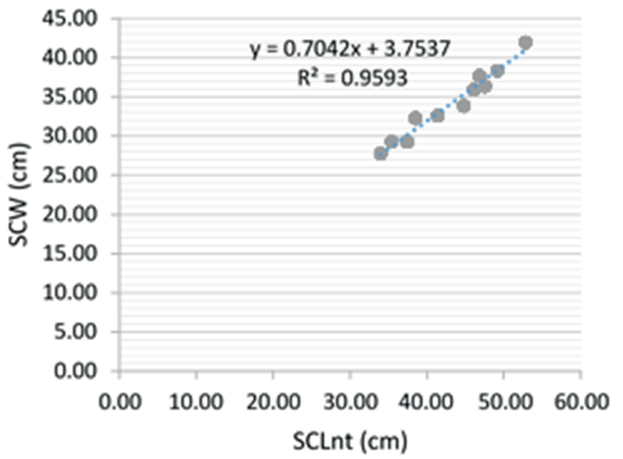

(b)

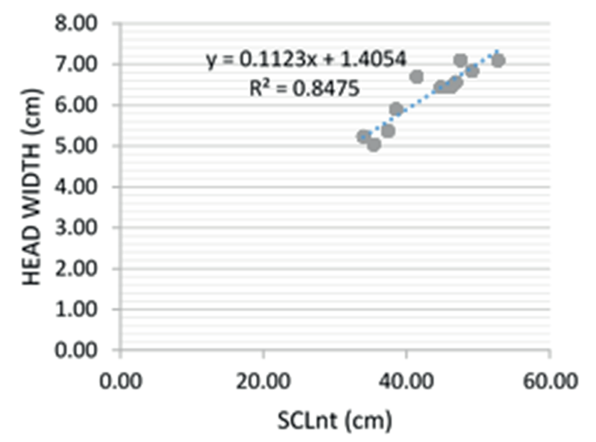

(d)

Figure 2: Correlation of straight carapace length with (a) Carapace surface area (b) Straight carapace width (c) Body mass and (d) Head width of hawksbill turtles in Maratua Island.

mass, and $\mathrm{R}^{2}=0.8475$ (correlation $=84.75 \%$ ) in SCLnt vs. Head Width. All comparisons showed a strong correlation, although in comparison with the head width is only $84.75 \%$. This likely occurred because hawksbills captured in this study are in the same age range. Overall, these results indicate that SCLnt had a big influence in the growth of hawksbill.

Based on the research by van Dam and Diez [7], body mass, SCW, SPML and head width is correlated linearly with the SCL. Then, according to Blumenthal et al. [9], body mass and SCL in the Western Caribbean hawksbill significantly associated with a correlation of $96 \%$, as well as in this study with a correlation of $98.51 \%$.

Based on Figure 3 can be seen a picture of geometry of the hawksbill turtle growth in Maratua with the smallest size (2014-2) to the largest (IDBooo9) with the range of SCLnt $33.97 \mathrm{~cm}$ to $52.80 \mathrm{~cm}$, the range of SCW $27.73 \mathrm{~cm}$ to $41.93 \mathrm{~cm}$ and the range of carapace surface area $763.79 \mathrm{~cm}^{2}$ to $1907.06 \mathrm{~cm}^{2}$. The geometry shows that the growth form of all turtles is relatively common and occurs only increase the size, although the landmarks (points on the geometry in Figure 3 ) of each individual in the order added not always the same lies. This geometry analysis done with only limited comparisons by $X Y$ coordinates because only 11 turtles were captured, but with this comparison can already be seen a simple description of the form of hawksbill growth in Maratua Island. Hawksbill carapace shaped like a heart (heart-shaped) in individuals that are 


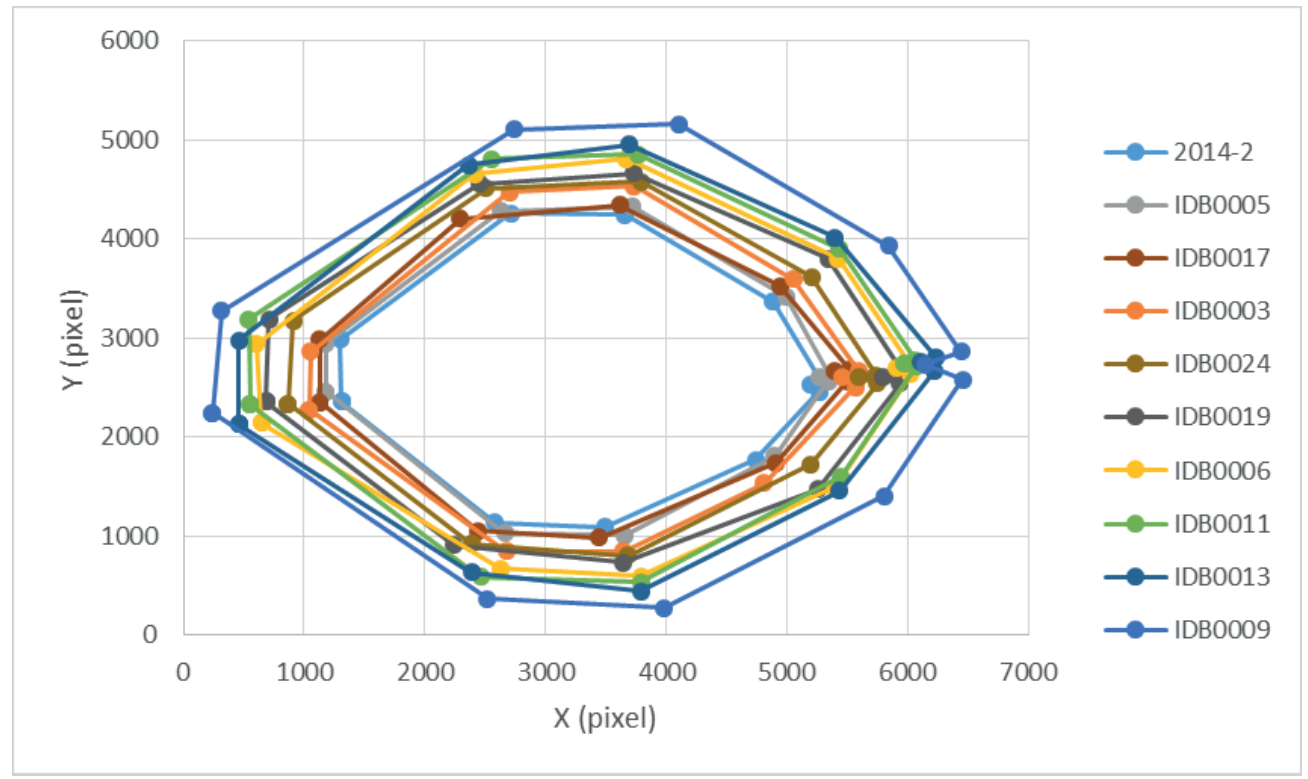

Figure 3: Geometry of hawksbill turtles carapace growth in Maratua Island.

very young (hatchlings) and then will change the shape in elongate that are oval or subovate [10]. Hawksbill carapace shape found in Maratua has an oval-subovate shape.

There is epibiosis with barnacles and algae on all the turtles were captured. On the carapace and plastron of each individual, there are a lot of algae attached on the middle to the posterior part. Sessile epibionts in carapace usually contained on the $1 / 3$ part of posterior, then some form of epibionts also found under the scales which overlap, namely in the vertebral scales, usually on the third and fourth vertebral scales of nuchal region [11]. This is likely due to the turtles habit that often hide behind a coral or stone with the posterior part on the inside, so that the middle and posterior part is less exposed. Parts that are less exposed to the possibility of a part of the most easily overcome by the algae and the algae can be protected from predators such as cleaning animals. Algae on the plastron was more than the algae attached on the carapace. In the flipper is usually only a few algae off, but in some individuals the ventral skin of the hind flipper and tail covered by a lot of algae. On the all of turtles neck and head are not observed the algae off.

Barnacle is an epibiont that most do epibiosis with turtles. In all turtles were captured, there are barnacles attached in different body parts. There are no barnacles on the carapace of all turtles, barnacles found to be present in the plastron, neck skin, flipper scales, flipper ventral skin and the skin on the tail. Barnacles that are found in this study identified as a member of the family Chelonibiidae. Barnacles most commonly found in the skin, but the barnacles are usually small to medium sized. Barnacles that attach to the plastron is usually a medium-sized to large as in Figure 4. 


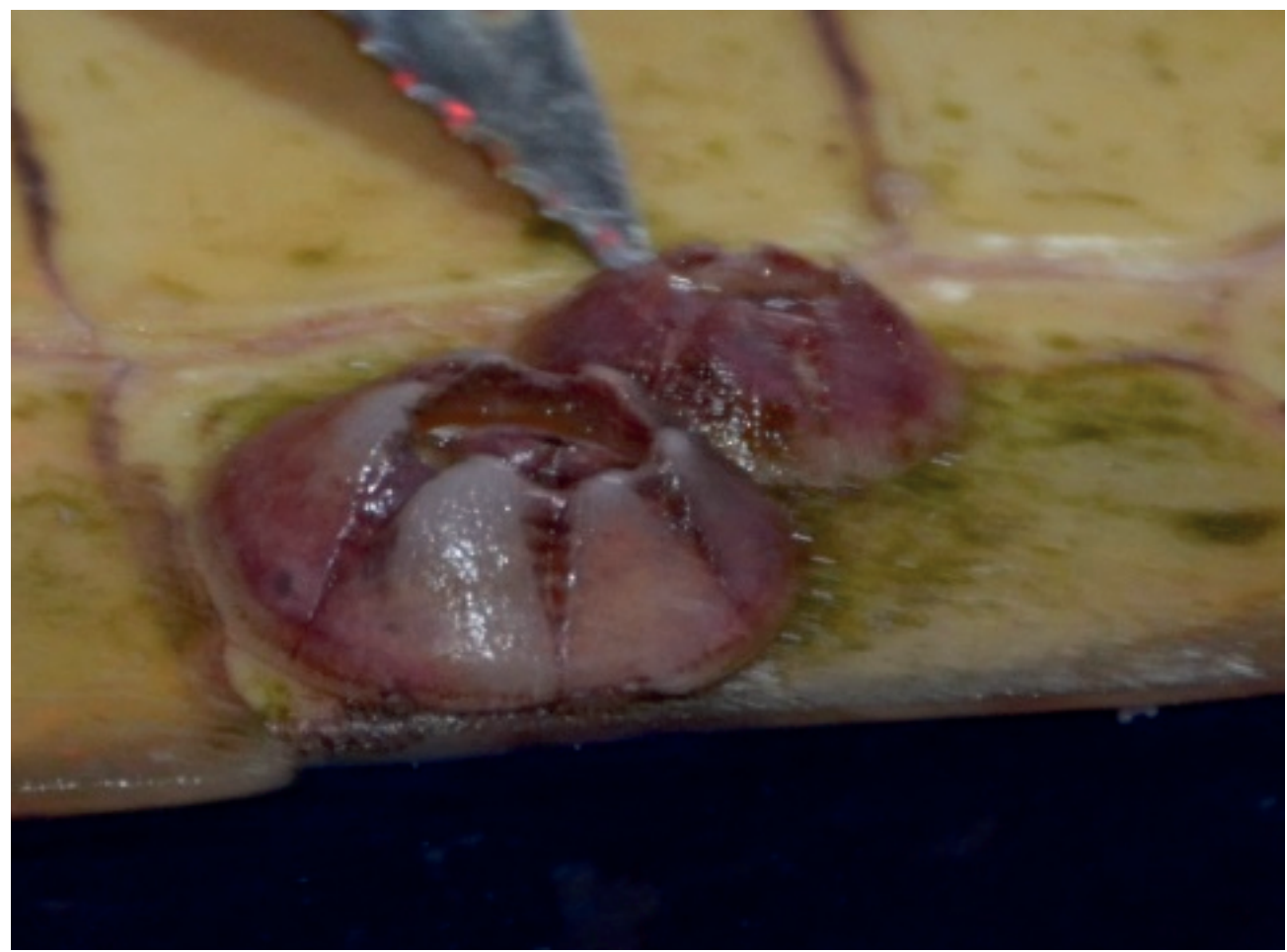

Figure 4: Barnacles that attached on plastron one of hawksbill in Maratua Island.

The barnacle is an epibiont that are "burrowing" so that it will leave a hole marks on the turtle.

Chelonibia (Chelonibiidae) is a group of barnacles that are the most frequently found on turtles. Based on study by Ling and Puspa [12] in Mabul and Sipadan Island, discovered species of barnacles Chelonibia testudinaria that epibiosis with hawksbill, in a previous study by Scharer [13] and Dobbs and Landry. [14] said that the barnacle species most commonly found on the hawksbill is Chelonibia caretto. According to the Epibiont Research Cooperative/ERC [15], barnacles of the genus Chelonibia, especially Chelonibia caretto commonly found on the carapace, flippers, skin, head and plastron, then Chelonibia testudinaria commonly found on the carapace, flippers, skin, head, plastron and nails. Chelonibia caretto and Chelonibia testudinaria reportedly found in the Pacific hawksbill turtle and Atlantic hawksbill turtles. This shows that the barnacles were found in this research in Maratua Island is indeed an epibiont that are generally found on hawksbill.

Physical damage that may occur as a result of non-biotic factors just look at the turtle IDBoo03, there are scratches on vetebral scale and marginal scale. This can occur due to many factors, for example, is in contact with a sharp stone or coral or a collision with a ship. Not observed any damage caused by the presence of fishing activities (hunting turtle). Hawksbill usually located in the reef-edge zone and swim to the surface only to take a breath, after take a breath hawksbill was usually immediately swam quickly toward depth. This possibility makes hawksbill had less likely to accidentally hit or get 


\begin{tabular}{|c|c|c|}
\hline Turtles & Body Condition Index & Interpretation \\
\hline $2014-2$ & 0.95 & Poor \\
\hline IDBoo5 & 1.04 & Average \\
\hline IDBo17 & 0.92 & Poor \\
\hline IDBoo3 & 1.08 & Average \\
\hline IDBo24 & 1.07 & Poor \\
\hline IDBo19 & 1.10 & Good \\
\hline Turtles & Body Condition Index & Interpretation \\
\hline IDBoo6 & 1.12 & Good \\
\hline IDBo11 & 1.14 & Good \\
\hline IDBo21 & 1.09 & Average \\
\hline IDB013 & 1.03 & Average \\
\hline IDBoo9 & 1.09 & Average \\
\hline Mean & $1.05 \pm 0.06$ & Average \\
\hline
\end{tabular}

TABLE 2: Body Condition Index of hawksbill turtles in Maratua Island.

hit by a ship. At this time, active hunting by Maratua local peoples are very rarely performed. Several local peoples only hunt when accidentally met the hawksbill.

Based on it Body Condition Index (Table 2), hawksbill in Maratua found in this study had an average health interpretation. Based on research by Najera-Hillman et al. [16] using the Body Condition Index said that green turtles were epibiosis with barnacles (C. testudinaria) have a lower Body Condition Index than that do not, but the difference was not significant that the presence of barnacles can not be used as a leading indicator of the health condition of the turtle. Barnacle abundance was not correlated with body size turtle. Similarly in this study, turtle that has a lot of barnacles on it body do not necessarily have a lower Body Condition Index as turtle 2014-2 has a poor Body Condition Index but it only has a few barnacles attached. Compared to turtle IDBo009, IDBooo6 and IDBo011 which has a good Body Condition Index but has a lots of barnacles attached. This suggests that the presence of barnacles not significantly affect Body Condition Index of turtles and turtle health conditions certainly influenced by many other factors.

According to Najera-Hillman et al. [16] the effect of the presence of barnacles with the health condition of the turtle still cannot be used as a reference for certain, but it can be used as an alternative data about the health condition of the turtle. The existence of barnacles usually have negative effects such as providing hydrodynamic barriers when turtles swimming. In addition, many factors that influence health conditions such as the size of the turtle, seasons, turtle habits and migration patterns of sea turtles. Specific indicators such as hematological and biochemical parameters can also be used as an indicator of health. Hawksbill in Maratua can be said to be relatively 
healthy because from the observations the epibiosis with barnacles and algae does not at extreme amount and does not interfere the survival and habit of hawksbill.

According to study by Bjorndal and Bolten [17], hawksbill in Union Creek Reserve (UCR) in coral reef zone-hardbottom zone has a mean of Body Condition Index 1.17 \pm 0.08 ( $n=45)$ with the index range from 1.05 to 1.41. Then it compared well with the research by Diez and van Dam [18] which states hawksbill in the foraging zone in Little Cayman has a mean of Body Condition Index $1.25 \pm 0.17$ and $1.24 \pm 0.18$ in Grand Cayman. This indicate that turtles are in the foraging zone is likely to have a high Body Condition Index because it was at the productive time and high level of consumption. Compared with this study, hawksbill in Maratua has a lower index (even though there are only 11 turtles). Hawksbill were found in this study is almost entirely found in the reef-edge zones and coral reefs at a depth of $5 \mathrm{~m}$ to $10 \mathrm{~m}$. As it is known that the foraging zone of hawksbill is the coral reef areas, but the results found in this study is the hawskbills has a low Body Condition Index. This is likely because just a fewer turtles captured or indeed Maratua Island waters is not the main foraging zone for hawksbill. Research on the zone status of Maratua Island waters for hawksbill is needs to be done further for sure.

\section{Conclusions}

Hawksbill turtles growth in straight carapace length affect the growth of the body such as the straight carapace width, carapace surface area, body mass and head width. The growth form of hawksbill turtles are found in this study unchanged and only have added size. The health status through observation of epibiota, mechanical damage, and analysis of Body Condition Index, hawksbill turtles in Maratua still relatively healthy compared with studies elsewhere.

\section{Acknowledgements}

We are very grateful to the U. S. Fish and Wildlife Service and the German Eva Mayr Stihl Foundation for their generous financial support of this study. Many thanks also go to all local peoples of Maratua Island, especially who provided a shelter.

\section{References}

[1] A. Al Giffari, "Partisipasi masyarakat dalam program konservasi penyu (Kasus I kawasan konservasilLaut Kabupaten Berau, Kepulauan Derawan, Provinsi Kalimantan Timur, [Participant of community in turtle conservation programme (Case I coservation sea area in Berau District, Derawan Island, East Borneo Province)], 
[Undergraduated thesis]," Institut Pertanian Bogor, 2008.

[2] A. Rahman and R. Basuki, "Materi penyuluhan kelautan dan perikanan konservasi biota terancam punah Penyu Sisik. [Sea counseling and fisheries conservation biota endangered Hawksbill Turtle material]., Jakarta," Kementrian Kelautan dan Perikanan Badan Pengembangan SDM Kelautan dan Perikanan Pusat Penyuluhan Kelautan dan Perikanan, pp. 18-19, 2011, [in Bahasa Indonesia].

[3] EG. Wilson, KL. Miller, D. Allison, and M. Magliocca, "Why healthy oceans need sea turtles: the importance of sea turtles to marine ecosystems," Why healthy oceans need sea turtles: the importance of sea turtles to marine ecosystems, p. 7, 2010.

[4] J. M. Daza and V. P. Páez, "Morphometric variation and its effect on reproductive potential in female Colombian slider turtles (Trachemys callirostris callirostris)," Herpetologica, vol. 63, no. 2, pp. 125-134, 2007.

[5] GIWA, "Freshwater shortages, engineering of river flows, pollution and overfishing highlighted in final global international waters assessment. Nairobi: United Nations Environment Programme," p. 58, 2006.

[6] M. A. Stamper, C. Harms, S. P. Epperly, J. Braun-McNeill, L. Avens, and M. K. Stoskopf, "Relationship between barnacle epibiotic load and hematologic parameters in loggerhead sea turtles (Caretta caretta), a comparison between migratory and residential animals in Pamlico Sound, North Carolina," Journal of Zoo and Wildlife Medicine, vol. 36, no. 4, pp. 635-641, 2005.

[7] R. P. Van Dam and C. E. Diez, "Caribbean hawksbill turtle morphometrics," Bulletin of Marine Science, vol. 62, no. 1, pp. 145-155, 1998.

[8] M. Flint, J. Patterson?Kane, P. Mills, and C. Limpus, "A Veterinarians guide for Sea Turtle post mortem examination and histological investigation," in Patterson $\square$ Kane J, p. 21, Queensland, The University of Queensland, 2009.

[9] J. M. Blumenthal, T. J. Austin, C. D. L. Bell et al., "Ecology of hawksbill turtles, Eretmochelys imbricata, on a western caribbean foraging ground," Chelonian Conservation and Biology, vol. 8, no. 1, pp. 1-10, 2009.

[10] US. Fish, "Wildlife Service. South Florida multi-species recovery plan," in $h$ and Wildlife Service, p. 615, U.S. Fish, Atlanta, Georgia, 1999.

[11] MG. Frick, PA. Mason, KL. Williams, K. Andrews, and H. Gerstung, "Epibionts of Hawksbill Turtle in a Caribbean nesting ground: A potentially unique association with snapping shrimp (Crustacea: Alpheidae). Marine Turtle Newsletter," in Gerstung H. Epibionts of Hawksbill Turtle in a Caribbean nesting ground: A potentially unique association with snapping shrimp (Crustacea: Alpheidae). Marine Turtle Newsletter, p. 99, 99, 8-11, 2003.

[12] OS. Ling and MP. Puspa, "Silent Turtle Dwellers: Barnacles on resident Green Turtle (Chelonia mydas) and Hawksbill Turtle (Eretmochelys imbricata) of Mabul and Sipadan Islands. Borneo Science," in Puspa MP. Silent Turtle Dwellers: Barnocles on resident Green Turtle (Chelonia mydas) and Hawksbill Turtle (Eretmochelys imbricata) of Mabul and Sipadan Islands. Borneo Science, Pp. 28-66, 28, 66-71, 2011.

[13] M. T. Schärer, "A survey of the epibiota of Eretmochelys imbricata (Testudines: Cheloniidae) of Mona Island, Puerto Rico," Revista de Biologia Tropical, vol. 51, no. 4, pp. 87-90, 2003. 
[14] KA. Dobbs and AM. Jr Landry, "Commensals on nesting Hawksbill Turtles (Eretmochelys imbricata," Memoirs of the Queensland Museum, pp. 649-674, 2004.

[15] R. Hayashi, "First documentation of the barnacle Fistulobalanus albicostatus (Cirripedia: Balanomorpha) as an epibiont of loggerhead sea turtle Caretta caretta," Marine Biodiversity, vol. 47, pp. 157-158, 2017.

[16] E. Nájera-Hillman, J. B. Bass, and S. Buckham, "Distribution patterns of the barnacle, Chelonibia testudinaria, on juvenile green turtles (Chelonia mydas) in Bahia Magdalena, Mexico," Revista Mexicana de Biodiversidad, vol. 83, no. 4, pp. 1171-1179, 2012.

[17] K. A. Bjorndal and A. B. Bolten, "Hawksbill sea turtles in seagrass pastures: Success in a peripheral habitat," Marine Biology, vol. 157, no. 1, pp. 135-145, 2009.

[18] C. E. Diez and R. P. Van Dam, "Habitat effect on hawksbill turtle growth rates on feeding grounds at Mona and Monito Islands, Puerto Rico," Marine Ecology Progress Series, vol. 234, pp. 301-309, 2002. 